\title{
Variation in home range size and patterns in adult female American crocodiles Crocodylus acutus
}

\author{
Jeffrey S. Beauchamp ${ }^{1,3, *}$, Kristen M. Hart ${ }^{2}$, Michael S. Cherkiss ${ }^{2}$, Frank J. Mazzotti ${ }^{1}$ \\ ${ }^{1}$ University of Florida, Fort Lauderdale, Florida 33314, USA \\ ${ }^{2}$ US Geological Survey, Wetland and Aquatic Research Center, Davie, Florida 33314, USA \\ ${ }^{3}$ Present address: US Fish and Wildlife Service, Bitter Lake National Wildlife Refuge, Roswell, New Mexico 88201, USA
}

\begin{abstract}
The American crocodile Crocodylus acutus is a threatened species that uses relatively deep, open-water habitats with low salinity. Adult female American crocodiles nest on sandy coastal beaches, islands or human-made berms, assist in the hatching process, and can travel long distances to nesting habitat. We satellite-tracked 15 adult female American crocodiles in 2 hydrologically distinct areas in Everglades National Park, Florida, USA, to quantify the home range sizes, test for intraspecific differences in home range and core area size and structure, and identify important crocodile high-use areas. Overall home ranges (95\% kernel density estimate; KDE) for adult female crocodiles in South Florida ranged from 30.0 to $141.9 \mathrm{~km}^{2}$ (mean $\pm \mathrm{SD}, 84.4 \pm$ $\left.32.3 \mathrm{~km}^{2}\right)$, and core areas (50\% KDE) ranged from 4.7 to $27.4 \mathrm{~km}^{2}\left(17.8 \pm 7.3 \mathrm{~km}^{2}\right)$. We identified patterns in home range and core area overlap, seasonally shifting patterns in core area use, and the Fox Lake complex as an important crocodile high-use area. As the population of American crocodiles continues to grow and expand into new areas, it is important for conservation managers to understand individual crocodile habitat-use patterns and spatial resource requirements.
\end{abstract}

KEY WORDS: Crocodylus acutus $\cdot$ American crocodile $\cdot$ Everglades $\cdot$ Satellite telemetry $\cdot$ Home range $\cdot$ Endangered species $\cdot$ Intraspecific variation

\section{INTRODUCTION}

The American crocodile Crocodylus acutus is a large, upper trophic level predator that uses relatively deep, open-water habitats with low salinity (less than $15 \mathrm{ppt}$ ) that are protected from wind and wave activity (Kushlan \& Mazzotti 1989a). The range of the American crocodile includes coastal areas in northern South America, the Caribbean, Mexico, Central America, and southern Florida, USA, where it occurs from Vero Beach to Tampa Bay (Kushlan \& Mazzotti 1989b). In 1975, the American crocodile was listed as endangered by the US Fish and Wildlife Service (USFWS 1975), and, due to an increase in number of individuals and nests (Mazzotti et al. 2007a), was reclassified as threatened in 2007 (USFWS 2007). In addition to the USFWS designa-

${ }^{*}$ Corresponding author: jeffrey_beauchamp@fws.gov tion, the International Union for Conservation of Nature lists the American crocodile as Vulnerable throughout its range, and in most range States the species is listed in Appendix I of the Convention on International Trade in Endangered Species of Wild Flora and Fauna. Much is known about the population biology and nesting ecology of American crocodiles, but limited information is available on their spatial ecology, beyond that obtained in earlier work carried out in Florida (Mazzotti 1983, Kushlan \& Mazzotti 1989a) and Panama (Rodda 1984, Balaguera-Reina et al. 2016).

The identification of factors that influence size, location, and structure of home ranges has been the focus of studies across multiple taxa and is particularly important for species in need of conservation (Cooke 2008). Determining critical conservation

(C) J.S.B., F.J.M. and, outside the USA, the US Government 2018. Open Access under Creative Commons by Attribution Licence. Use, distribution and reproduction are unrestricted. Authors and original publication must be credited. 
areas, including stopover locations for migratory wildlife, important nesting areas, or high-use foraging habitat, is important for developing effective management strategies. For nesting species, the distance between foraging and nesting habitats is an important determinant of how those species orient themselves in the landscape. Smith (1995) examined foraging behavior of wading birds in Florida and determined that the length of their flights during the nesting season was driven by the distance from foraging to nesting habitat. Similarly, Odum \& Kuenzler (1955) reported that some birds decrease their home range size when foraging for nestlings as opposed to during the nest-building season, when their home range sizes are larger. Kay (2004) tracked saltwater crocodiles C. porosus and found that female crocodiles traveled considerable distances to their nesting sites. Hutton (1989) and Joanen \& McNease (1970) found that Nile crocodile $C$. niloticus and American alligator Alligator mississippienesis females have smaller home ranges than males due to the proximity of nesting sites to foraging sites. Kushlan \& Mazzotti (1989a) analyzed home range areas for American crocodiles in South Florida and reported that nesting females can have 2 separate activity areas. Additionally, Tucker et al. (1997) described nest site fidelity in adult female Australian freshwater crocodiles $C$. johnstoni.

Female American crocodiles excavate their nests, assist in the hatching process (Ogden \& Singletary 1973), and appear to reach sexual maturity at $2.25 \mathrm{~m}$ total length (Kushlan \& Mazzotti 1989b). They can travel long distances with the newly hatched crocodiles, but generally do not show the signs of prolonged parental care (Kushlan \& Mazzotti 1989b) that are seen in other crocodilians (Cott 1971, Kushlan \& Kushlan 1980). American crocodiles nest communally with some nests as close as $1 \mathrm{~m}$ from each other, and aggregations of adult females can be observed in proximity to each other during the nesting season (J. S. Beauchamp, University of Florida, pers. obs.). It has long been thought that American crocodiles rarely tolerate adult conspecifics of the same sex unless they are congregated at breeding sites or in captivity (Lang 1987). During the nesting season, adult female American crocodiles can travel up to $35.5 \mathrm{~km}$ (Cherkiss et al. 2007) to nesting habitat that generally consists of sandy coastal beaches, islands or human-made berms, such as those created by dredging activities. Most of the nesting in the historic nesting area of northeastern Florida Bay (NFB) takes place on keys within the bay, on coastal beaches sometimes located at a considerable distance (10s of $\mathrm{km}$ ) from foraging and nursery habitat, or on banks of creeks draining into Florida Bay (Mazzotti 1999). At Cape Sable (CS), an area with a greatly increased contribution to nesting in the early 2000s (Mazzotti et al. 2007b), nesting activity is mostly on berms created from the dredging of the East Cape and Homestead Canals and is adjacent to ideal foraging habitat, although there is considerable nesting along the coastal beaches of CS that is farther from known foraging habitat. Identifying how adult female crocodiles in South Florida occupy their space is important as crocodiles continue to recover and expand their range into unoccupied habitat. Moreover, identifying high-use areas that may be affected by ecosystem restoration will help managers and researchers to prioritize restoration projects.

The objectives of our research were to: (1) quantify home range sizes of adult female American crocodiles in South Florida, (2) identify important crocodile use areas in South Florida, and (3) test for intraspecific differences in home range and core area size and structure between 2 hydrologically distinct nesting areas (NFB and CS). From what has been published on other nesting species and the nesting biology of American crocodiles, we a priori hypothesized that we would detect a seasonal (nesting vs. non-nesting) change in spatial use patterns of American crocodiles in South Florida. We predicted that crocodiles at CS will have a greater level of spatial sharing during the nesting season due to the known nesting aggregations, and crocodiles at NFB will have a greater shift in their home ranges due to the distance from nesting habitat to foraging habitat when they transition from nesting to non-nesting season.

\section{MATERIALS AND METHODS}

\section{Study area}

Everglades National Park (ENP) is a 1.5 million acre (approximately $607000 \mathrm{ha}$ ) Wetland of International Importance, World Heritage Site, and International Bioreserve. We conducted this study at 2 sites within ENP (Fig. 1), the historic crocodile nesting area of NFB, and the more recently discovered nesting area of CS. The hydrology of NFB is primarily driven by the Taylor Slough drainage. Vegetation in NFB is dominated by red mangrove Rhizophora mangle forest and scrub with interspersed black mangrove Avicennia germinans forests and hardwood hammocks. Egler (1952) described the herbaceous wetlands in NFB as dominated by spikerush 


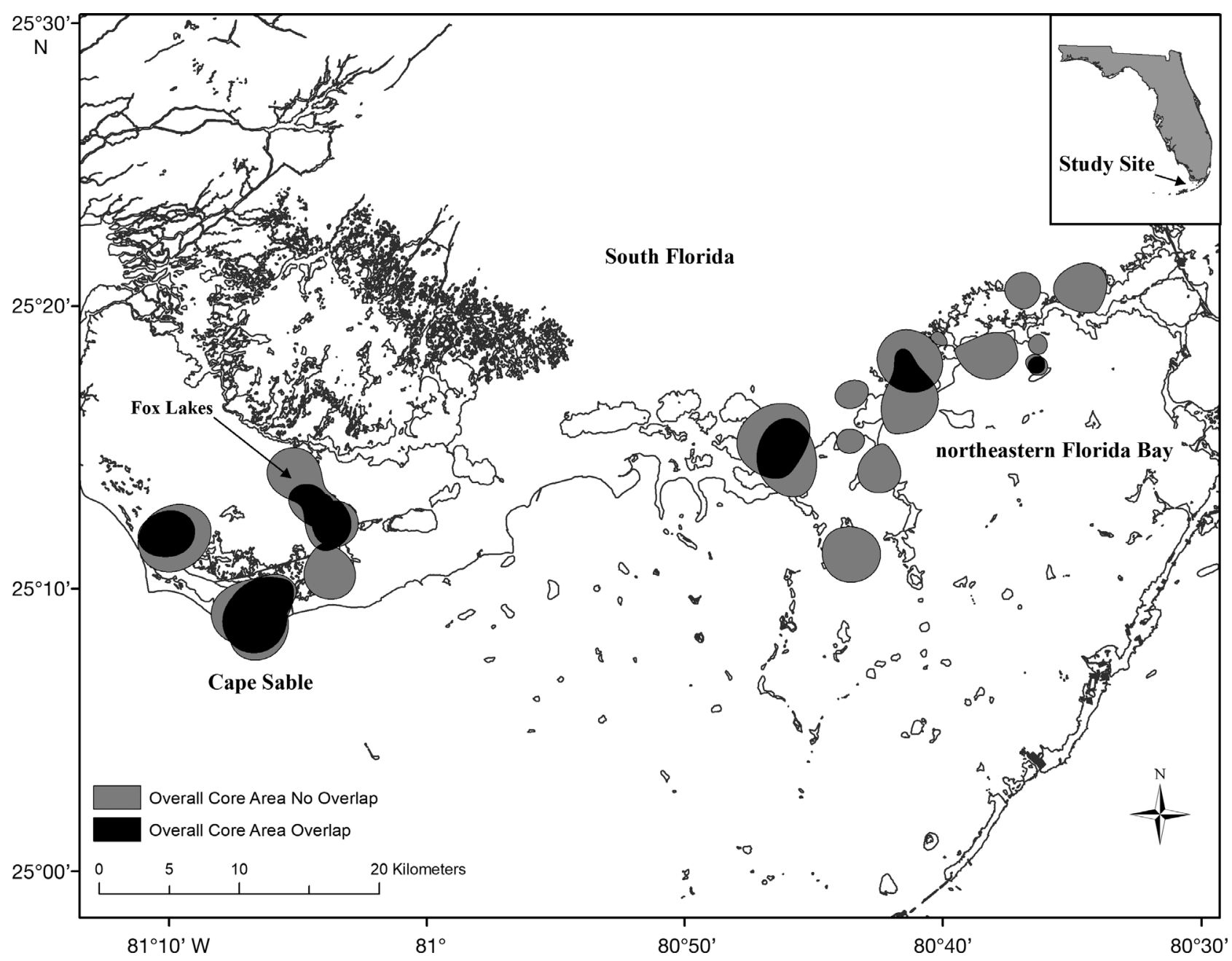

Fig. 1. Everglades National Park, South Florida, USA, with the 2 study sites Cape Sable and northeastern Florida Bay. Overall core areas (50\% kernel density estimate; KDE) of adult female American crocodiles Crocodylus acutus are indicated

Eleocharis cellulosa with some clumps of sawgrass Cladium jamaicense. These wetlands have all but vanished from coastal habitats of NFB due to the changes in hydrology (Lorenz \& Serafy 2006). Diverted freshwater flow and salinity patterns in NFB are currently the target of restoration (USACE \& SFWMD 2011). Lack of fresh water in NFB has been correlated with lower growth and survival of crocodiles (Mazzotti \& Cherkiss 2003, Mazzotti et al. 2007a).

At CS, the hydrology is more influenced by the tide and rainfall compared with NFB. Salinities are consistently close to those found in sea water (approximately 30 ppt) along the coast, but may be fresher inland near the Fox Lakes complex. Black mangroves dominate the forest structure with red mangroves becoming more prevalent inland, especially surrounding lakes and ponds. Additionally, CS has an expanse of mud banks that become more exposed at low tide, as well as salt-tolerant herbaceous species interspersed between the mud banks and mangrove forests (Roberts et al. 1977). The human-made canals in CS were dredged through a marl ridge from the coastline into the freshwater interior for navigation as well as land for agriculture and cattle grazing. The canals triggered substantial change by altering salinity, increasing sediment deposition, and increasing erosion across the landscape (United States National Park Service 2008). The East Cape and Homestead Canals were plugged by the US National Park Service and US Army Corps of Engineers in 1986, 1990, and more recently in 2011 to retain fresh water in interior marshes and prevent saltwater intrusion (Mazzotti et al. 2007a,b). An increase in crocodile nesting coincided with the initial plugging of the canal in 1986 (Mazzotti et al. 2007a,b). 


\section{Live capture and handling}

We captured all crocodiles using self-locking snares (Thompson Snares), working from both motorboats and land. We marked each crocodile with a distinct scute clip pattern using established protocols (Mazzotti 1983, Mazzotti \& Cherkiss 2003) and measured head length, snout-vent length, total length, and tail girth to the nearest $\mathrm{mm}$, and mass to the nearest $\mathrm{kg}$. After taking morphometric measurements, we attached a satellite transmitter (Wildlife Computers, SPOT5, $0.5 \mathrm{~W}$, $70 \mathrm{~mm}$ long, $41 \mathrm{~mm}$ wide, $27 \mathrm{~mm}$ high, $110 \mathrm{~g}$ ) and a VHF radio-transmitter (Holohil, model SI-2, $40 \mathrm{~mm}$ long, $11 \mathrm{~mm}$ diameter, $13 \mathrm{~g}$ ) to each crocodile. The VHF transmitter was attached to locate animals if their satellite transmitter stopped transmitting. Attachment protocols followed Brien et al. (2010) with slight modifications to the equipment (needle and wire sizes) to account for the smaller size of American crocodiles. During the hatching season (end of June to September 15), we only attached transmitters on females known to have hatched their nest. Since adult female American crocodiles excavate their nests, assist hatchlings as they emerge from their shells, and remove hatchling crocodiles from a nest, we waited to capture the nesting females to ensure that this research did not result in crocodiles abandoning their nests (Kushlan \& Mazzotti 1989a). We programmed satellite transmitters to transmit every hour for the length of their deployment, and locations were determined by the Argos system which gives an accuracy location class (LC) to each position. Location class accuracies are designated as follows with error accuracy in parenthesis: LC3 (<250 m), LC2 (250 to $500 \mathrm{~m}), \mathrm{LC} 1$ (500 to $1500 \mathrm{~m})$, LC0 (>1500 m), LCA (unknown), LCB (unknown), LCZ (failed). Since 2011, Argos locations have been Kalman-filtered as opposed to least-squares filtered. This significantly improves the location accuracy (Lopez \& Malarde 2011). For this study, we used LC3 to LC1 for home range and core area analysis.

\section{Analysis}

We performed all statistical analyses in $\mathrm{R}$ ( $\mathrm{R}$ Core Team 2013) and determined statistical significance at $\alpha=0.05$. To determine home range size, we used fixed kernel density estimates (KDE) to put less emphasis on peripheral locations and eliminate areas that crocodiles may travel through only briefly (Worton 1989). This method allows for a more accurate representation of home range and core area because American croc- odiles are known to travel long distances to nesting sites. We also selected KDE to compare current home ranges to those reported in previously published literature. To minimize spatial autocorrelation, we calculated a mean daily location for each crocodile in $\mathrm{R}$, when more than 1 signal was acquired by the Argos system, and then we used $\mathrm{R}$ and the package 'adehabitatHR' with the reference ('href') smoothing parameter (Calenge 2015) to create KDEs. We used 50\% and $95 \%$ isopleths to depict core areas (50\% KDE) and overall home ranges (95\% KDE) of the telemetered crocodiles (following Worton 1989).

To determine intraspecific differences in seasonal habitat use within home ranges and core areas, we calculated KDEs (both 50 and 95\%) during the nesting (March 15 to September 15) and non-nesting (September 16 to March 14) seasons (Kushlan \& Mazzotti 1989b) using 'adehabitatHR' and calculated the centroid of each core area using 'rgeos' (Bivend et al. 2017) in R. We measured the distance between the nesting season centroid and non-nesting season centroid to determine if there was a seasonal shift in core areas. Additionally, we created a $500 \times 500 \mathrm{~m}$ grid across the study sites in ArcGIS (Environmental Systems Research Institute 2011) and calculated the number of crocodile-tracking days in each grid cell using LC3 locations to show areas of concentrated use; the spatial error of LC3 is less than the $500 \mathrm{~m}$ grid cell size. As a proxy for 'territoriality' and to determine the level of shared use, we used 'adehabitatHR' to calculate the percent overlap (95 and 50) of each crocodile's KDE and calculated the utilization distribution overlap index (UDOI; Fieberg \& Kochanny 2005). We then used a linear mixed effects model in R using 'lme4' (Bates et al. 2013) and 'lmerTest' (Kuznetsova et al. 2017) to test the effects of size (total length), fixes (number of daily locations), season (nesting vs. non-nesting) and the nested interaction between season and location on both the home range (LMMhr) and core area (LMMca) sizes. We excluded weight and length of transmitting time because they were highly correlated to total length and number of daily locations. We selected the individual crocodile as the random effect to help account for individual variation in the dataset.

\section{RESULTS}

\section{Home ranges and core-use areas}

We deployed satellite tags on 15 adult female crocodiles, 8 in CS and 7 in NFB, with satellite data col- 
lected from December 2010 to May 2013. Crocodiles ranged in total length from 235.8 to $303.5 \mathrm{~cm}$ (Table 1). Satellite-tracking periods ranged from $3 \mathrm{~d}$ to over $406 \mathrm{~d}$ (mean $\pm \mathrm{SD}, 196 \pm 104 \mathrm{~d}$ ). It is unclear why 1 transmitter lasted only $3 \mathrm{~d}$ at CS, although we observed a crocodile at NFB whose transmitter lasted $58 \mathrm{~d}$ with a missing antenna. Transmitters that were attached after this observation were reinforced at the base of the antenna at the factory, thereby minimizing additional losses due to antenna failure. The crocodile whose tracking time only lasted $3 \mathrm{~d}$ is not included in the analysis. All remaining crocodiles had more than 20 daily fixes (most with multiple high-quality locations per day). Two crocodiles in NFB only received fixes during the nesting season.

Overall home ranges (95\% KDE) for adult female crocodiles in South Florida ranged from 30.0 to $141.9 \mathrm{~km}^{2}(84.4 \pm$ $\left.32.3 \mathrm{~km}^{2}\right)$, and core areas $(50 \% \mathrm{KDE})$ ranged from 4.7 to $27.4 \mathrm{~km}^{2}\left(17.8 \pm 7.3 \mathrm{~km}^{2}\right)$, with variation by season (Table 2). Results from both the LMMhr and LMMca showed no significant effect of total length, number of daily locations, season or differences between the nesting season at CS and NFB on home range and core area sizes (Table 2). There were significant differ- ences between non-nesting season home range $(\mathrm{p}=$ $0.01)$ and core area $(p=0.02)$ sizes between CS and NFB: crocodiles at NFB had significantly smaller nonnesting sizes (Table 2). One female (\#5631) tagged at CS moved to the Fox Lake complex before the start of the nesting season and remained in that area throughout the nesting season. This site is approxi-

Table 2. Nested linear mixed effect model with home range (95\% kernel density estimate; KDE) and core area (50\% KDE) sizes as the response variables. Fixed effects include: Fixes (the number of daily locations); Length (total length of each crocodile); Season; Nesting season with Location (Cape Sable [CS] vs. northeastern Florida Bay [NFB]); and Non-nesting season with Location (CS vs. NFB). Individual crocodile is the random effect. Significant values are given in bold

\begin{tabular}{|lrrrrr|}
\hline & Estimate & SE & df & t-value & p-value \\
\hline Home range (95\% KDE) & & & & & \\
Intercept & 96.88 & 118.05 & 9.97 & 0.82 & 0.43 \\
Fixes & -0.11 & 0.13 & 10.62 & -0.85 & 0.41 \\
Length & -0.07 & 0.41 & 9.99 & -0.16 & 0.87 \\
Season & 27.54 & 20.34 & 12.16 & 1.35 & 0.20 \\
SeasonNesting/LocationNFB & 10.87 & 20.47 & 19.40 & 0.53 & 0.60 \\
SeasonNon-nesting/LocationNFB & -59.02 & 22.10 & 19.86 & -2.67 & $\mathbf{0 . 0 1}$ \\
Core area (50\% KDE) & & & & & \\
Intercept & 34.61 & 30.00 & 10.28 & 1.15 & 0.28 \\
Fixes & -0.05 & 0.03 & 11.75 & -1.60 & 0.14 \\
Length & -0.05 & 0.11 & 10.23 & -0.46 & 0.65 \\
Season & 4.18 & 4.31 & 12.61 & 0.97 & 0.35 \\
SeasonNesting/LocationNFB & 0.79 & 4.83 & 17.75 & 0.16 & 0.87 \\
SeasonNon-nesting/LocationNFB & -13.53 & 5.15 & 19.18 & -2.63 & $\mathbf{0 . 0 2}$ \\
\hline
\end{tabular}

Table 1. Summary for each American crocodile Crocodylus acutus captured and analyzed during this study. TL: total length. Home range (95\% kernel density estimate; KDE) and core area (50\% KDE) are measured in $\mathrm{km}^{2}$. Dates are given as mo/d/yr. na: not available

\begin{tabular}{|c|c|c|c|c|c|c|c|c|c|}
\hline \multirow{2}{*}{ ID } & \multirow{2}{*}{ Date captured } & \multirow{2}{*}{$\begin{array}{c}\text { Number of } \\
\text { daily locations }\end{array}$} & \multirow{2}{*}{$\mathrm{TL}(\mathrm{cm})$} & \multicolumn{2}{|c|}{$\ldots$} & \multicolumn{2}{|c|}{$\ldots$ Nesting season -} & \multicolumn{2}{|c|}{ Non-nesting season } \\
\hline & & & & Home range & Core area & Home range & Core area & Home range & Core area \\
\hline \multicolumn{10}{|c|}{ Cape Sable } \\
\hline 202 & $2 / 21 / 2012$ & 370 & 275.8 & 141.9 & 24.2 & 12.4 & 3.1 & 156.5 & 25.2 \\
\hline 1548 & $3 / 14 / 2012$ & 393 & 256.0 & 31.8 & 4.7 & 24.5 & 3.5 & 41.9 & 6.9 \\
\hline 5058 & $12 / 22 / 2010$ & 141 & 235.8 & 128.0 & 24.1 & 93.2 & 21.3 & 86.0 & 19.6 \\
\hline 5151 & $7 / 11 / 2012$ & 102 & 293.3 & 91.6 & 21.3 & 103.6 & 24.2 & 100.9 & 24.4 \\
\hline 5631 & $1 / 14 / 2011$ & 109 & 303.5 & 80.1 & 19.8 & 27.9 & 5.1 & 76.3 & 19.5 \\
\hline 6620 & $2 / 21 / 2012$ & 133 & 249.5 & 100.4 & 27.4 & 100.8 & 27.0 & 140.4 & 37.5 \\
\hline 6628 & $3 / 13 / 2012$ & 324 & 262.6 & 73.2 & 13.6 & 81.8 & 16.3 & 71.2 & 13.6 \\
\hline Mean & & $224.6 \pm 131.1$ & $268.1 \pm 24.2$ & $92.4 \pm 36.5$ & $19.3 \pm 7.8$ & $63.5 \pm 40.0$ & $14.3 \pm 10.3$ & $96.1 \pm 40.2$ & $21.0 \pm 9.6$ \\
\hline \multicolumn{10}{|c|}{ Northeastern Florida Bay } \\
\hline 481 & $7 / 12 / 2012$ & 263 & 266.4 & 85.1 & 15.3 & 113.6 & 25.7 & 21.4 & 3.5 \\
\hline 575 & $5 / 2 / 2012$ & 124 & 257.6 & 30.0 & 5.5 & 32.8 & 6.1 & 6.7 & 1.0 \\
\hline 775 & $4 / 27 / 2012$ & 250 & 251.7 & 60.7 & 10.3 & 63.9 & 13.8 & 47.7 & 6.7 \\
\hline 792 & $5 / 9 / 2011$ & 51 & 287.1 & 110.0 & 18.3 & 110.0 & 18.3 & na & na \\
\hline 1076 & $7 / 6 / 2012$ & 73 & 255.7 & 83.4 & 21.5 & 86.6 & 21.8 & 46.6 & 10.7 \\
\hline 1760 & $5 / 2 / 2012$ & 319 & 250.0 & 60.7 & 16.0 & 41.0 & 8.1 & 65.7 & 16.0 \\
\hline 6700 & $4 / 26 / 2012$ & 43 & 290.1 & 104.5 & 27.3 & 104.5 & 27.3 & na & na \\
\hline Mean & & $160.4 \pm 114.3$ & $265.5 \pm 16.6$ & $76.3 \pm 30.0$ & $16.3 \pm 7.1$ & $78.9 \pm 33.4$ & $17.3 \pm 8.3$ & $37.6 \pm 23.4$ & $7.6 \pm 5.9$ \\
\hline All crc & diles $($ mean $\pm \mathrm{SD})$ & $192.5 \pm 122.8$ & $266.8 \pm 20.0$ & $84.4 \pm 32.3$ & $17.8 \pm 7.3$ & $71.2 \pm 36.3$ & $15.8 \pm 9.1$ & $71.8 \pm 44.6$ & $15.4 \pm 10.5$ \\
\hline
\end{tabular}


mately $7 \mathrm{~km}$ from any known nesting areas and we postulate this female did not nest during the tracking period. Another female at NFB (\#481) hatched her nest in mid-July and was subsequently captured and tagged. She then moved to an inland area, approximately $9 \mathrm{~km}$ from her nest, and remained there until she moved back to the exact same nesting location (within less than $1 \mathrm{~m}$ ) the following March where she successfully hatched another nest.

\section{Shifting core areas and shared use}

The mean distance between the centroids of an individual crocodile's core area during the nesting and non-nesting season was $2.7 \pm 1.4 \mathrm{~km}$ and $3.1 \pm$ $3.3 \mathrm{~km}$ for NFB and CS, respectively. Although not significant $(W=14, \mathrm{p}=0.64$, Wilcoxon), there was considerable variability in the mean distance between seasonal centroids. Crocodiles at NFB shifted their core area at least $0.7 \mathrm{~km}$ and the largest shift was $4.0 \mathrm{~km}$. Crocodiles at CS either shifted a considerable distance $(9.4,5.1$, and $3.7 \mathrm{~km})$ or barely shifted at all $(0.4,0.7,1.7$, and $0.3 \mathrm{~km})$. Two crocodiles at CS that shifted their core areas a large distance likely nested along the western coast of Florida, a considerable distance from the capture location and presumed foraging area. The third crocodile moved farther inland to the Fox Lake complex and likely did not nest. The 3 crocodiles that did not have a large shift in core area nested near presumed foraging habitat.

There was extensive overlap in home range, core area, and UDOI at CS (Fig. 2). Each satellite-marked crocodile at CS shared its core area with at least 1 other satellite-marked crocodile, and 4 of the 7 shared their core area with 5 other crocodiles (Fig. 1). All crocodiles captured at CS that were tracked during the same time period shared their core area with at least 1 other crocodile; only 3 of the 6 crocodiles captured at NFB that were tracked during the same time period shared a small portion of their core area with another crocodile. Crocodiles at CS had significantly more overlap in all 3 metrics (home range, core area, and UDOI) in all 3 time intervals (nesting, non-nesting, and overall) than crocodiles at NFB except for nesting season home range $(W=35, \mathrm{p}=0.21$, Wilcoxon). Additionally, crocodiles at CS significantly increased their home range $(W=6, \mathrm{p}=0.02$, Wilcoxon) and UDOI ( $W=0, \mathrm{p}=0.00$, Wilcoxon) overlap during the non-nesting season, but not their core area overlap ( $W=11, \mathrm{p}=0.10$, Wilcoxon). The crocodiles at NFB did not have a significant seasonal change $(W=19, \mathrm{p}=0.88)$ in their overlap patterns.
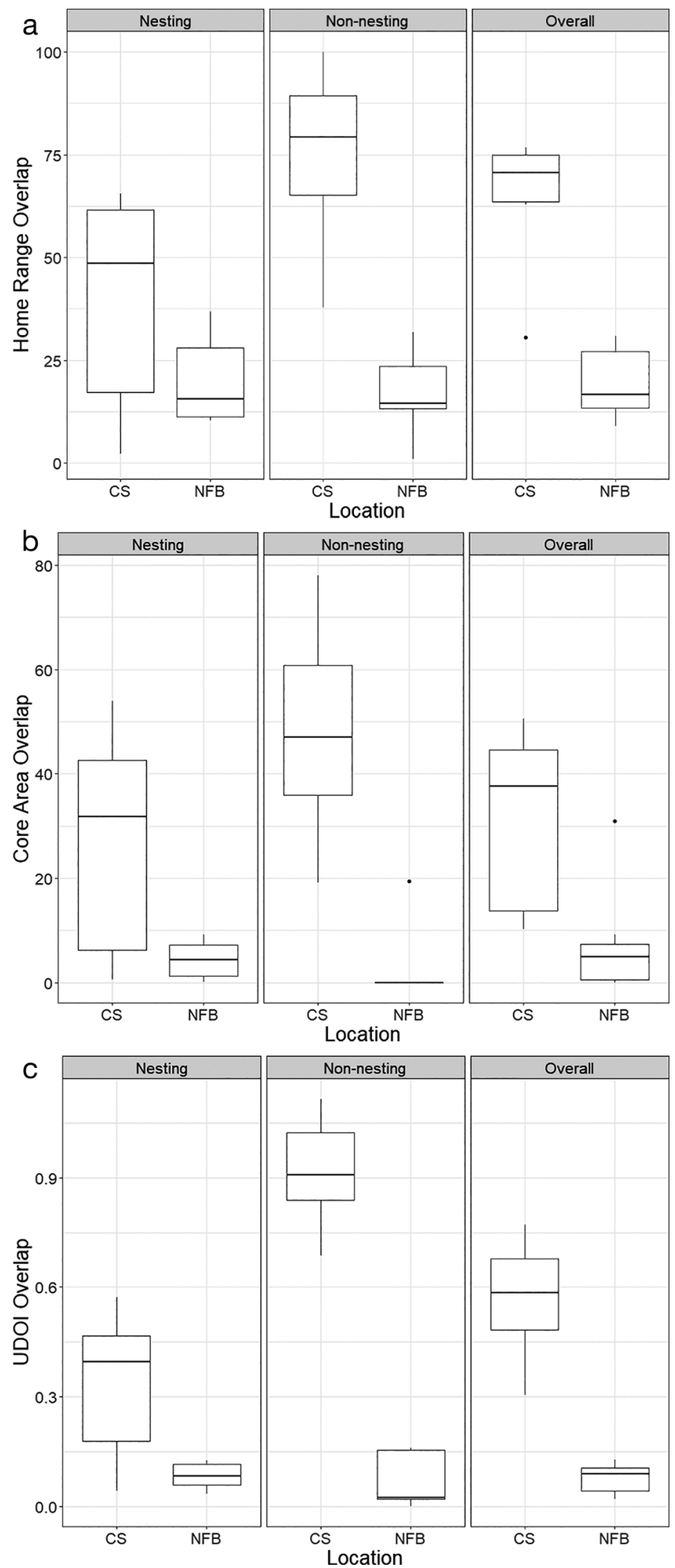

Fig. 2. Home range (95\% kernel density estimate; KDE), core area $(50 \% \mathrm{KDE})$ and utilization distribution overlap index (UDOI) for adult female American crocodiles Crocodylus acutus in Everglades National Park, Florida, USA. Locations are Cape Sable (CS) and northeastern Florida Bay (NFB). The horizontal bar in each box shows the 50th percentile (median), the upper and lower boundaries of each box show the 75th and 25th percentiles, respectively. The whiskers are $1.5 \times$ interquartile range and black dots are outliers. Home range and core area are percent overlap 


\section{DISCUSSION}

We provide the first estimates of home range size and patterns of habitat use for adult female American crocodiles using satellite telemetry, and show intraspecific variation between individuals using 2 hydrologically different nesting areas. Compared with previously reported home range estimates for American crocodiles, the results of our study reveal much larger areas of spatial use. The use of satellite tags (this study) versus VHF radio tags may have allowed for detection of larger home ranges. For example, Kushlan \& Mazzotti (1989a) reported an average home range size of 107 ha (approximately $1.1 \mathrm{~km}^{2}$ ) for 5 crocodiles in South Florida using VHF transmitters. Coastal habitats in South Florida (both studies) are dominated by dense mangroves which make access and navigation by boat and foot difficult. The ability of satellite transmitters to continue to receive signals in areas inaccessible or otherwise impossible to track on the ground likely resulted in the larger home ranges reported in this study. Recent work in Panama by Balaguera-Reina et al. (2016) estimated home range sizes for American crocodiles but we are hesitant to make any statistical comparisons because they reported the mean $\pm \mathrm{SD}$ for all individuals, and then pooled individuals within each size class and sex; our research shows crocodiles can have considerable intraspecific variability in their home range and core area sizes.

Other than saltwater crocodiles and American alligators, limited data are available to make spatial use comparisons with other adult female crocodilians. For alligators, Joanen \& McNease (1970), Goodwin \& Marion (1979), Rootes \& Chabreck (1993), Taylor (1984), Morea et al. (2000), and Fujisaki et al. (2014) all reported markedly smaller home range sizes across a number of habitats than the present study, but this was expected because female alligators tend to move more during the spring breeding season, and limit their movements during the summer nesting and hatching season, as well as the winter season when they typically find a den to avoid cold temperatures (Chabreck 1965, Joanen \& McNease 1970, Goodwin \& Marion 1979). Home range values for adult female saltwater crocodiles are variable. Brien et al. (2008) reported smaller home ranges than the present study at a seasonally isolated water hole in northern Queensland, Australia. Kay (2004) and Campbell et al. (2013) reported smaller home range values than the present study for saltwater crocodiles in riverine systems in Australia, and used a linear approach in their home range analysis. American crocodiles in Florida are not as restricted in their movements as saltwater crocodiles in Australia that occupy riverine or isolated water holes, so it is not surprising that home ranges reported in the present study are larger.

There was considerable intraspecific variation in home range, core area, and UDOI overlap between the 2 nesting areas (CS and NFB). Both Kay (2004) and Campbell et al. (2013) showed that adult male saltwater crocodiles can have overlapping home ranges in a riverine system, whereas Brien et al. (2008) found overlap in adult males, but very little overlap in adult female saltwater crocodiles in an inland pond during the dry season. Kushlan \& Mazzotti (1989a) described shared use between crocodiles in Florida, and our results corroborate those findings. However, we found very little overlap at NFB. This pattern of habitat use was different at CS where there was extensive overlap in home ranges, core areas, and UDOI (Fig. 2). All crocodiles at CS were captured and tagged at East Cape, whereas in NFB we captured crocodiles across the study site at each crocodile's nest location. It was difficult to target adult female crocodiles in NFB during the non-nesting season when they are generally away from habitat accessible by motorboat. This pattern of core area overlap is not likely due to where we captured the crocodiles or timing of transmitter deployment. Three crocodiles in NFB nested within $3 \mathrm{~km}$ of each other and shared very little nesting season core area overlap, and 2 other crocodiles in NFB nested within a few hundred meters of each other and did not share any nesting season overlap. Additionally, 2 of the areas where overlap occurred at CS were approximately $8 \mathrm{~km}$ from the capture locations. Notably, each of the 7 crocodiles that were tagged in CS made trips to the Fox Lake complex with repeated and sometimes extended stays; approximately $23 \%$ of all locations at CS occurred within or near the Fox Lake complex (Fig. 3). This area is known to have large numbers of adult crocodiles (J. S. Beauchamp pers. obs.), particularly during the winter just before onset of nesting (i.e. January). Additionally, all 5 of the crocodiles at CS that shared temporal overlap all shared a large proportion of their core areas and only 3 of the 6 that shared temporal overlap at NFB shared a small portion of their core areas.

One potential explanation that may explain the overlap observed in this study is the result of a simple restoration project at CS. Mazzotti et al. $(2007 \mathrm{a}, \mathrm{b})$ hypothesized that an increase in nesting at CS was due to plugging of canals to retain fresh water in interior water bodies and to prevent salt water intru- 


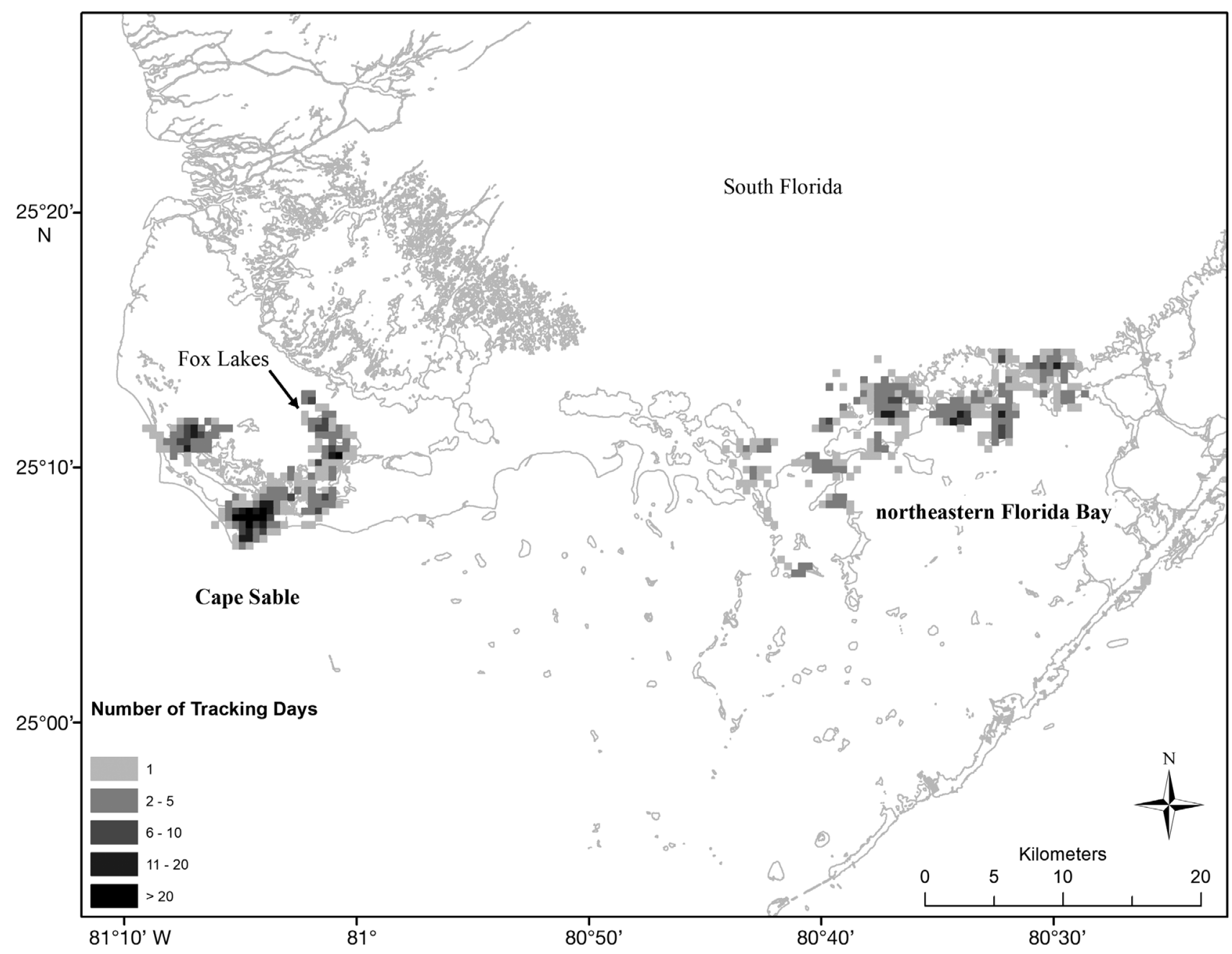

Fig. 3. Combined number of tracking days per $500 \mathrm{~m}$ grid cell for adult female American crocodiles Crocodylus acutus in Everglades National Park, South Florida, USA

sion. Additionally, Mazzotti et al. (2009) hypothesized that lower salinities in the CS interior due to plugging canals also improved growth and survival of crocodiles, leading to an increase in their relative density at CS. In addition to the lower salinities, the Fox Lake complex could also provide enhanced mating opportunities and a plentiful food source that make crocodiles more tolerant of one another. The improved food resources from low salinities and higher density of crocodiles are probably why we have both larger non-nesting season home ranges and more overlap at CS. Understanding why this area can support the amount of spatial sharing by adult female crocodiles will be important for managing this threatened species.

Initially, we predicted that crocodiles at NFB would have a greater shift between their nesting and nonnesting season home ranges and core areas due to most of the nesting in NFB occurring farther from foraging habitat than nesting at CS. This pattern did emerge, but some of the CS crocodiles either did not nest or nested along the western coast of Florida, which is a considerable distance from preferred foraging habitat. Additionally, frequent or extended trips to the Fox Lake complex by the CS crocodiles was an important finding and these trips most likely influenced the shifting core area use pattern at CS.

The results of this study demonstrate that adult female American crocodiles can be tolerant of conspecifics given enough habitat and resources. As the large and ambitious effort to restore hydrologic patterns in the Greater Everglades to near historic flows continues, understanding how those landscape changes may affect animals, particularly upper trophic level species, is critical. Previous work by Mazzotti (1999) and Mazzotti et al. (2009) showed that Ameri- 
can crocodiles have altered vital rates (i.e. growth, survival, and nesting) in response to changing hydrology. If freshwater flows increase into the South Florida estuary through restoration efforts, historic food webs may respond and create increased foraging opportunities for crocodiles. We expect to see not only an increase in numbers, growth, survival, and nesting of crocodiles, but also an increase in shared spatial use patterns in NFB as a result of current restoration projects such as the C-111 Canal West Spreader Project (USACE \& SFWMD 2011). Lorenz \& Serafy (2006) reported that fish populations in the South Florida estuary decrease during times of increased salinity, and if restoration stalls or climate change increases salinity levels in the Everglades estuary, we expect crocodiles to continue to have limited spatial overlap with the corresponding decrease in prey (i.e. fish).

\section{Implications}

As the population of American crocodiles continues to grow and expand into new areas it is important to know how much and what kind of habitat is needed to sustain a healthy population. American crocodiles are known to move long distances to nest sites (Cherkiss et al. 2007) and nuisance crocodiles have been recorded making long distance movements after relocation. For example, a male American crocodile was released in Naples, FL, and recaptured in Miami, FL, a distance of approximately $344 \mathrm{~km}$ (Cherkiss et al. 2014). The results of our tracking work show that adult female American crocodiles have large home ranges that most likely include a suite of habitats. Previous work by Rosenblatt \& Heithaus (2011) on American alligators in South Florida showed the importance of highly mobile top predators to dispersal of nutrients across the landscape and creation of habitat linkages. The crocodiles tracked in this study may be creating the same linkages across the South Florida ecosystem by having large home ranges. Additionally, we identified 2 intraspecific spatial patterns-shifting seasonal core areas and spatial overlap-that will allow American crocodiles greater flexibility as habitats change or their range continues to expand into unoccupied habitat.

Most of the differences identified in home range size and movement patterns for crocodilians have been attributed to sex and size. Crespo et al. (2015) reported that juvenile American crocodiles in Florida can move more than $69 \mathrm{~km}$ between capture events. Understanding how male and non-adult American crocodiles are moving and using space within the landscape would enhance our understanding of the spatial habitat use patterns and extent of this species. Notably, none of the females tagged in this study moved between the 2 study sites. Adult male American crocodiles may have larger home ranges, as identified in other crocodilians (Tucker et al. 1997, Morea et al. 2000, Kay 2004, Brien et al. 2008, Wang et al. 2011), that could possibly link these 2 geographic areas. The increase in observations of crocodiles in urban areas (L. Horde, Florida Fish and Wildlife Conservation Commission, pers. comm.) also increases the potential for human-crocodile interactions. Additional satellite- or GPS-tracking of crocodiles with quantification of home range and core areas and their overlap would be beneficial for managers charged with designing strategies to protect both humans and crocodiles in these urban areas. This research also shows the importance of the Fox Lake complex to crocodiles in South Florida, and management actions intended to sustain that habitat could likely be beneficial to crocodiles. Additional research on movement modelling and how American crocodiles respond to environmental changes either from climate change or restoration efforts could allow researchers and managers to better understand the environmental parameters that influence and shape movement patterns.

Acknowledgements. Funding for our study was provided by the US Geological Survey, Priority Ecosystem Science Program, and Save Your Logo, Fonds de Dotation pour la Biodiversité. Permission to capture and tag crocodiles was given under ENP permit \#EVER-2012-SCI-0021, USFWS permit \#TE077258-1, University of Florida IACUC \#002-11FTL, and University of Florida ARC \#002-08FTL. Field assistance was provided by M. Denton, R. Lynch, M. Rochford, G. Blakemore, E. Larrivee, B. Jeffery, A. Crowder, and R. Crespo. A previous version of this manuscript was greatly helped by the review of Rob Fletcher and Allison Benscoter. This manuscript is dedicated to Rafael Crespo whose work with crocodiles in Florida will never be forgotten. The findings and conclusions in this article are those of the author(s) and do not necessarily represent the views of the US Fish and Wildlife Service. The use of trade, firm, or product names is for descriptive purposes only and does not imply endorsement by the US Government.

\section{LITERATURE CITED}

Balaguera-Reina SA, Venegas-Anaya M, Sanchez A, Arbelaez I, Lessios HA, Densmore LD III (2016) Spatial ecology of the American crocodile in a tropical Pacific island in Central America. PLOS ONE 11:e0157152

Bates B, Maechler M, Bolker B, Walker S (2013) lme4: Linear mixed-effects models using Eigen and S4. R package 
version 1.0-5. http://cran.r-project.org/package=lme4

Bivend R, Rundal C, Pebesma E, Stuetz R, Hufthammer KO (2017) rgeos: Interface to Geometry Engine - Open Source ('GEOS') using the C 'API' for topology operations on geometries. $\mathrm{R}$ package version 0.3-26

Brien ML, Read MA, McCallum HI, Grigg GC (2008) Home range and movements of radio-tracked estuarine crocodiles (Crocodylus porosus) within a non-tidal waterhole. Wildl Res 35:140-149

Brien ML, Webb GJW, Manolis C, Lindner G, Ottway D (2010) A method for attaching tracking devices to crocodilians. Herpetol Rev 41:305-308

* Calenge C (2015) adehabitatHR: A collection of tools for the estimate of animals home range. $\mathrm{R}$ package version 0.4.14. https://cran.r-project.org/web/packages/adehabitatHR/ vignettes/adehabitatHR.pdf

Campbell HA, Dwyer RG, Irwin TR, Franklin CE (2013) Home range utilization and long-range movement of estuarine crocodiles during the breeding and nesting season. PLOS ONE 8:e62127

Chabreck RH (1965) The movement of alligators in Louisiana. Proc Southeast Ass Game Fish Comm 19: 102-110

Cherkiss MS, Parry MA, Mazzotti FJ (2007) Crocodylus acutus (American crocodile). Migration. Herpetol Rev 38: 72-73

Cherkiss MS, Mazzotti FJ, Hord L, Aldecoa M (2014) Remarkable movements of an American crocodile (Crocodylus acutus) in Florida. Southeast Nat 13:N52-N56

Cooke SJ (2008) Biotelemetry and biologging in endangered species research and animal conservation: relevance to regional, national, and IUCN Red List threat assessments. Endang Species Res 4:165-185

Cott HB (1971) Parental care in the Crocodilia, with special reference to Crocodylus niloticus. Crocodiles. Proc 1st Working Meeting Crocodile Specialists, Bronx Zoo, New York, 15-17 March 1971. IUCN Publications New Series 32:166-180

Crespo R, Beauchamp JS, Mazzotti FJ, Cherkiss MS (2015) Crocodylus acutus (American crocodile). Long distance juvenile movement. Herpetol Rev 46:623-624

Egler FE (1952) Southeast saline Everglades vegetation, Florida and its management. Vegetatio 3:213-265

Environmental Systems Research Institute (2011) ArcGIS Desktop: Release 10. Esri, Redlands, CA

Fieberg J, Kochanny CO (2005) Quantifying home-range overlap: the importance of the utilization distribution. J Wildl Manage 69:1346-1359

Fujisaki I, Hart KM, Mazzotti FJ, Cherkiss MS and others (2014) Home range and movements of American alligators (Alligator mississippiensis) in an estuary habitat. Anim Biotelem 2:8

Goodwin TM, Marion WR (1979) Seasonal activity ranges and habitat preferences of adult alligators in a north-central Florida lake. J Herpetol 13:157-163

Hutton J (1989) Movements, home range, dispersal and the separation of size classes in Nile crocodiles. Am Zoo 29:1033-1049

Joanen T, McNease L (1970) A telemetric study of nesting female alligators on Rockefeller Refuge, Louisiana. Proc Annu Conf Southeast Ass Game Fish Comm 24:175-193

Kay WR (2004) Movements and home ranges of radiotracked Crocodylus porosus in the Cambridge Gulf region of Western Australia. Wildl Res 31:495-508

Kushlan JA, Kushlan MS (1980) The function of nest atten- dance in the American alligator. Herpetologica 36:27-32

Kushlan JA, Mazzotti FJ (1989a) Population biology of the American crocodile. J Herpetol 23:7-21

K Kushlan JA, Mazzotti FJ (1989b) Historic and present distribution of the American crocodile in Florida. J Herpetol $23: 1-7$

KKuznetsova A, Brockhoff PB, Christensen RHB (2017) lmerTest package: tests in linear mixed effects models. J Stat Softw 82:1-26

Lang JW (1987) Crocodilian behaviour: implications for management. In: Grahame JW, Webb S, Manolis C, Whitehead PJ (eds) Wildlife management: crocodiles and alligators. Surrey Beatty, Sydney, p 273-294

Lopez R, Malarde JP (2011) Improving ARGOS Doppler location using Kalman filtering. Memorandum. CLS, Ramonville Saint-Agne. www.argos-system.org/wp-content/ uploads/2016/07/r282_9_technical_paper.pdf

* Lorenz JJ, Serafy JE (2006) Subtropical wetland fish assemblages and changing salinity regimes: implications for everglades restoration. Hydrobiologia 569:401-422

Mazzotti FJ (1983) Ecology of Crocodylus acutus in Florida. $\mathrm{PhD}$ thesis. Pennsylvania State University, University Park, PA

Mazzotti FJ (1999) The American crocodile in Florida Bay. Estuaries 22:552-561

Mazzotti FJ, Cherkiss MS (2003) Status and conservation of the American crocodile in Florida: recovering an endangered species while restoring an ecosystem. University of Florida, Ft. Lauderdale Research and Education Center Tech Rep 2003

Mazzotti FJ, Brandt LA, Moler PE, Cherkiss MS (2007a) American crocodile (Crocodylus acutus) in Florida: recommendations for endangered species recovery and ecosystem restoration. J Herpetol 41:122-131

Mazzotti FJ, Cherkiss MS, Parry MW, Rice KG (2007b) Recent nesting of the American crocodile (Crocodylus acutus) in Everglades National Park, Florida, USA. Herpetol Rev 38:285-289

Mazzotti FJ, Best GR, Brandt LA, Cherkiss MS, Jeffery BM, Rice KG (2009) Alligators and crocodiles as indicators for restoration of Everglades ecosystems. Ecol Indic 9: S137-S149

Morea CR, Rice KG, Percival H, Howater S (2000) Home range and daily movement of the American alligator in the Everglades. Crocodiles. Proc 15th Working Meeting of the IUCN-SSC Crocodile Specialist Group, Varadero, 17-20 January 2000, p 486-504

Odum EP, Kuenzler EJ (1955) Measurement of territory and home range size in birds. Auk 72:128-137

Ogden JC, Singletary C (1973) Night of the crocodile. Audubon 75:32-37

R Core Team (2013) R: a language and environment for statistical computing. R Foundation for Statistical Computing, Vienna. www.r-project.org

Roberts HH, Whelan T, Smith WG (1977) Holocene sedimentation at Cape Sable, South Florida. Sediment Geol 18:25-60

Rodda GH (1984) Movements of juvenile American crocodiles in Gatun Lake, Panama. Herpetologica 40:44-45

Rootes WL, Chabreck RH (1993) Reproductive status and movement of adult female alligators. J Herpetol 27 : 121-126

Kosenblatt AE, Heithaus MR (2011) Does variation in movement tactics and trophic interactions among American alligators create habitat linkages? J Anim Ecol 80:786-798 
Smith JP (1995) Foraging flights and habitat use of nesting wading birds (Ciconiiformes) at Lake Okeechobee, Florida. Colon Waterbirds 18:139-158

Taylor D (1984) Management implications of an adult female alligator telemetry study. Proc Annu Conf Southeast Fish Wildlife Agencies 38:222-227

Tucker AD, Limpus CJ, McCallum HI, McDonald KR (1997) Movements and home ranges of Crocodylus johnstoni in the Lynd River, Queensland. Wildl Res 24:379-396

United States National Park Service (2008) Natural resource management, Cape Sable canals. South Florida Natural Resources Center, Homestead, FL

USFWS (United States Fish and Wildlife Service) (1975) Listing of endangered and threatened fauna. Fed Regist 40: 44149-44151

USFWS (United States Fish and Wildlife Service) (2007) Endangered and threatened wildlife and plants; reclassi-

Editorial responsibility: Michael Mahony, Callaghan, New South Wales, Australia fication of the American crocodile distinct population segment in Florida from endangered to threatened. Fed Regist 72:13027-13041

USACE, SFWMD (2011) Central and Southern Florida Project Comprehensive Everglades Restoration Plan C-111 Spreader Canal Western Project Final Integrated Project Implementation Report and Environmental Impact Statement. United States Army Corps of Engineers, Jacksonville, FL, and South Florida Water Management District, West Palm Beach, FL

* Wang Z, Yao H, Ding Y, Thorbjarnarson J, Wang X (2011) Testing reintroduction as a conservation strategy for the critically endangered Chinese alligator: movements and home range of released captive individuals. Chin Sci Bull 56:2586-2593

*Worton BJ (1989) Kernel methods for estimating the utilization distribution in home-range studies. Ecology 70:164-168

Submitted: January 23, 2018; Accepted: May 5, 2018

Proofs received from author(s): July 3, 2018 